\title{
Gold nanoparticle-labeled biosensor for rapid and sensitive detection of bacterial pathogens
}

Yun Wang ${ }^{1,2}$ and Evangelyn C. Alocilja ${ }^{1 *}$

\begin{abstract}
Background: Escherichia coli O157:H7 is one of the major foodborne bacterial pathogens and also a biodefense agent. To ensure food safety and public health, it is very important to develop rapid methods for E. coli O157:H7 detection. In this study, we designed a nanoparticle-labeled biosensor for the rapid detection of E. coli O157:H7 in broth.

Results: Magnetic nanoparticles (MNPs) were conjugated with monoclonal antibodies (Abs) to separate target $E$. coli O157:H7 cells from broth samples. Gold nanoparticles (AuNPs) were conjugated with polyclonal Abs, and were then introduced to the MNP-target complex to form a sandwich MNP-target-AuNP. By measuring the amount of AuNPs through an electrochemical method, the presence and the amount of the target bacteria were determined. Results showed a sensitivity of $10^{1}$ colony forming units per milliliter (cfu/ml) with a linear range of $10^{1}-10^{6} \mathrm{cfu} / \mathrm{ml}$.

Conclusions: Compared to conventional culture plating methods, the biosensor reduced the detection time from 2 to 4 days to less than 1 hour with a simple target extraction method. The AuNP-labeled biosensor has potential applications in the rapid detection of infectious agents for public health, biodefense, and food/water safety.
\end{abstract}

Keywords: E. coli O157:H7, Biosensor, Rapid detection, Nanoparticles, Magnetic separation, Electrochemical measurement, Antibodies

\section{Background}

Rapid detection of pathogenic bacteria is critical to public health, biodefense, and food/water safety. Escherichia coli $\mathrm{O} 157: \mathrm{H7}$ is one of the major foodborne bacterial pathogens and also a biodefense agent. There were several outbreaks of $E$. coli $\mathrm{O} 157: \mathrm{H} 7$ in recent years that endangered public health [1-3]. Because conventional culture plating methods for E. coli O157:H7 take two to four days to obtain results, development of rapid detection methods for this organism is important. Biosensors are emerging technologies that have the potential for getting rapid results and that can be employed in the field. There are many biosensor configurations and approaches that are in the research and design stage. These configurations include antibody-based systems [4-8], enzyme-based detection $[9,10]$ and DNA-based sensors $[11,12]$. In addition to speed, biosensors have the potential to generate highly sensitive results. This is especially

\footnotetext{
* Correspondence: alocilja@msu.edu

${ }^{1}$ Department of Biosystems and Agricultural Engineering, Michigan State

University, East Lansing, Ml 48824, USA

Full list of author information is available at the end of the article
}

critical as many bacterial infections could be caused by as low as 10 organisms [13].

The application of nanomaterials in biosensors, such as nanoparticles with optical, electronic and magnetic properties, has drawn interest. Because of their unique characteristics, nanoparticles have been used to enhance sensor sensitivity either by increasing the capture efficiency of the target molecules or by utilizing the optical and electronic properties of the nanostructures to amplify signals. Magnetic nanoparticles were employed for separating targets for bacterial detection $[6,14,15]$. Gold nanoparticles (AuNPs) were used for signal amplification $[15,16]$. Polymeric nanoparticles were also introduced for signal amplification $[6,17]$.

In this paper, we developed an electrochemical biosensor using antibody-modified nanoparticles for the detection of E. coli O157:H7. Two novel nanoparticles were utilized in the biosensor design: 1) polymer-coated magnetic nanoparticles (MNPs) to separate the target bacteria from the sample matrix and carbohydrate-capped AuNPs to label the separated target by forming a sandwich structure and generate the signal. The signal of 
AuNPs for the corresponding target was measured by differential pulse voltammetry (DPV) on a screen printed carbon electrode (SPCE) chip. The biosensor enabled rapid pathogen detection in $45 \mathrm{~min}$ from sample preparation to final readout of results.

\section{Results and discussion}

Magnetic separation of target E. coli 0157:H7

E. coli $\mathrm{O} 157: \mathrm{H} 7$ cells were magnetically captured as shown in Fig. 1. We modified the $\mathrm{Fe}_{2} \mathrm{O}_{3}$ nanoparticles with polyaniline (PANI) for direct immobilization of anti-E. coli $\mathrm{O} 157: \mathrm{H} 7$ antibody (Ab). Figure 2 presents the transmission electron microscopy (TEM) images of the $\mathrm{Fe}_{2} \mathrm{O}_{3}$ nanoparticle core (Fig. 2a) and the PANIcoated MNPs (Fig. 2b) [18]. Figure 2a reveals that the average diameter of the $\mathrm{Fe}_{2} \mathrm{O}_{3}$ nanoparticle core is $20 \mathrm{~nm}$, while Fig. 2b shows that the PANI-coated MNPs have diameters ranging from 50 to $100 \mathrm{~nm}$. The increase of the diameter was due to the formation of PANI around the $\mathrm{Fe}_{2} \mathrm{O}_{3}$ core. According to the insets, the electron diffraction pattern in Fig. 2a exhibited a typical maghemite $\left(\gamma-\mathrm{Fe}_{2} \mathrm{O}_{3}\right)$ nanoparticle structure [19]. In Fig. $2 \mathrm{~b}$, the electron diffraction pattern shows a set of rings which are typical for PANI [20], noted that it has less bright spots than in Fig. 2a. This pattern also indicates the coating of $\mathrm{Fe}_{2} \mathrm{O}_{3}$ core by PANI.

Electrostatic interaction has been used to modify the PANI-coated MNPs with antibody. The interaction between the negatively charged Fc fragment of antibody molecules and the positively charged PANI contributes to the conjugation [18]. Figure 3a shows a schematic of the interaction between the PANI-coated MNPs and the antibody.

The MNP-Ab was used to magnetically separate the target from the sample through the antibody-antigen interaction. The scanning electron microscopy (SEM, Fig. 3b) confirms the capture of the target [6]. In this image, a rod-shaped E. coli $\mathrm{O} 157: \mathrm{H} 7$ cell is bound to MNP-Ab conjugate.

\section{AuNP-labeled biosensor for detection}

Figure 4 shows two typical sensorgrams of native AuNPs and native MNPs. Current peak for AuNPs is at $0.3 \mathrm{~V}$ and MNPs is at $0.58 \mathrm{~V}$. Figure 5 shows typical DPV sensorgrams for the detection of E. coli O157:H7 in different cell concentrations $\left(10^{2}, 10^{4}\right.$, and $10^{6}$ colony forming units per milliliter, cfu/ml). The sensorgrams show a wide curve that seems to include both AuNPs and MNPs. For the analysis, peak current to the left (representing AuNPs) around $0.3 \mathrm{~V}$ was chosen for signal reporting. As shown in the graph, peak current for AuNPs increased with increasing cell concentration. Figure 5 confirms the formation of the MNP-cell-AuNP complex. The amount of target cells detected was proportional to the amount of AuNPs.

A linear relationship between signal to noise ratio (SNR) and cell concentration is shown in Fig. 6, with an $\mathrm{R}^{2}$ value of 0.953 . The SNR was calculated as the peak current of AuNPs for each concentration divided by the current at $0.3 \mathrm{~V}$ of the blank, which was used as the

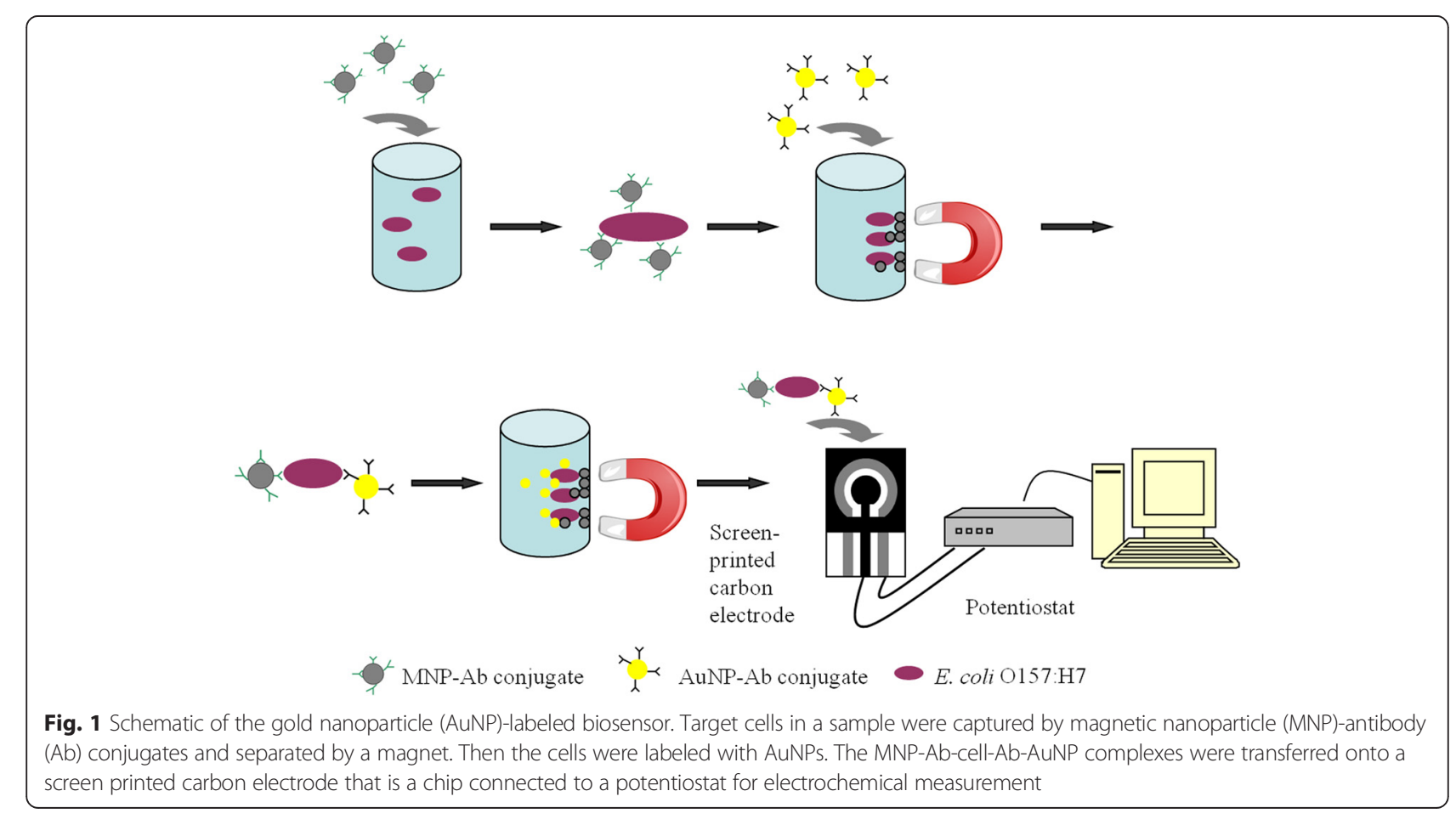




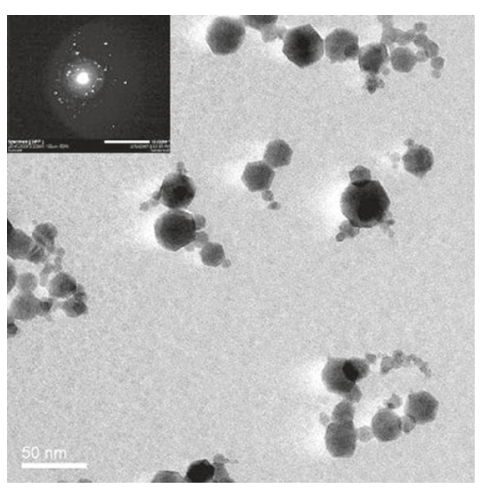

a

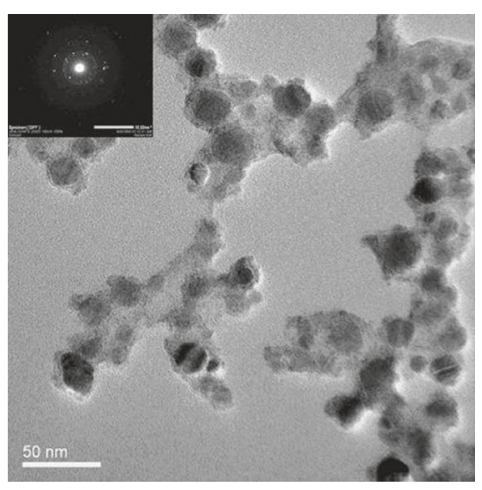

b

Fig. 2 Polyaniline (PANI)-coated magnetic nanoparticles (MNPS). Transmission electron microscopy (TEM) images of: (a) Fe $\mathrm{O}_{3}$ core; (b) PANI-coated MNPs. The insets show the electron diffraction patterns of the nanoparticles [18]. Used with permission from Biosensors \& Bioelectronics
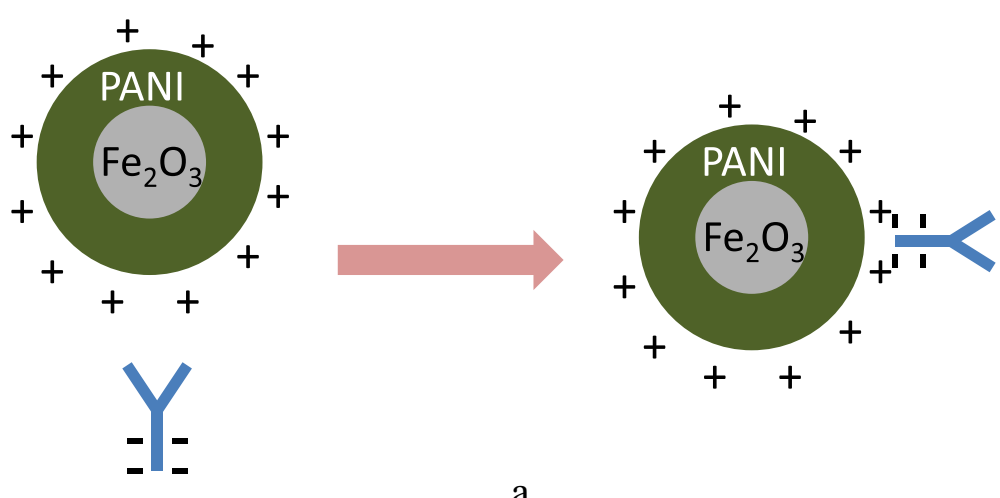

a

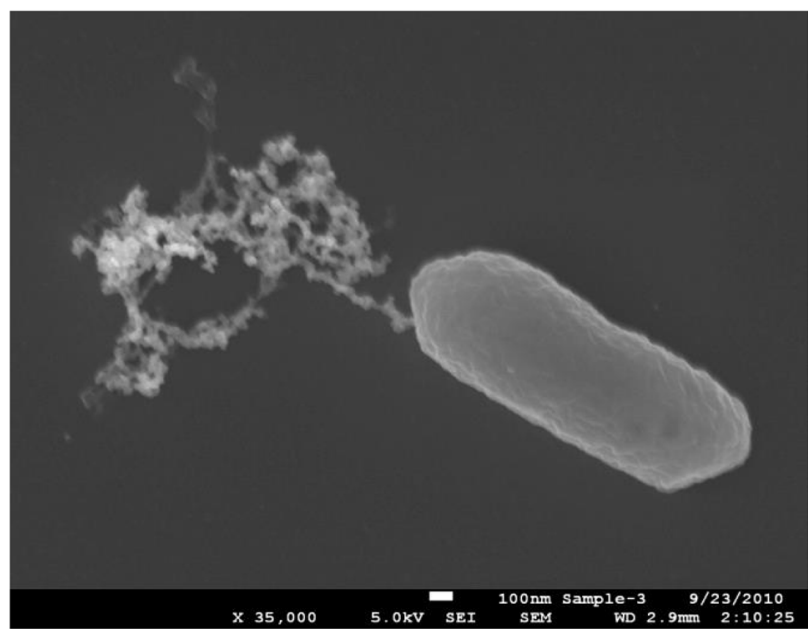

b

Fig. 3 a Schematic of the conjugation of Polyaniline (PANI)-coated magnetic nanoparticles (MNPs) and antibody; and (b) Scanning electron microscopy (SEM) image of an antibody-conjugated MNP bound to an E.coli O157:H7 cell [6]; used with permission from International Journal of Food Safety, Nutrition and Public Health (Inderscience retains copyright of the original article and figure) 


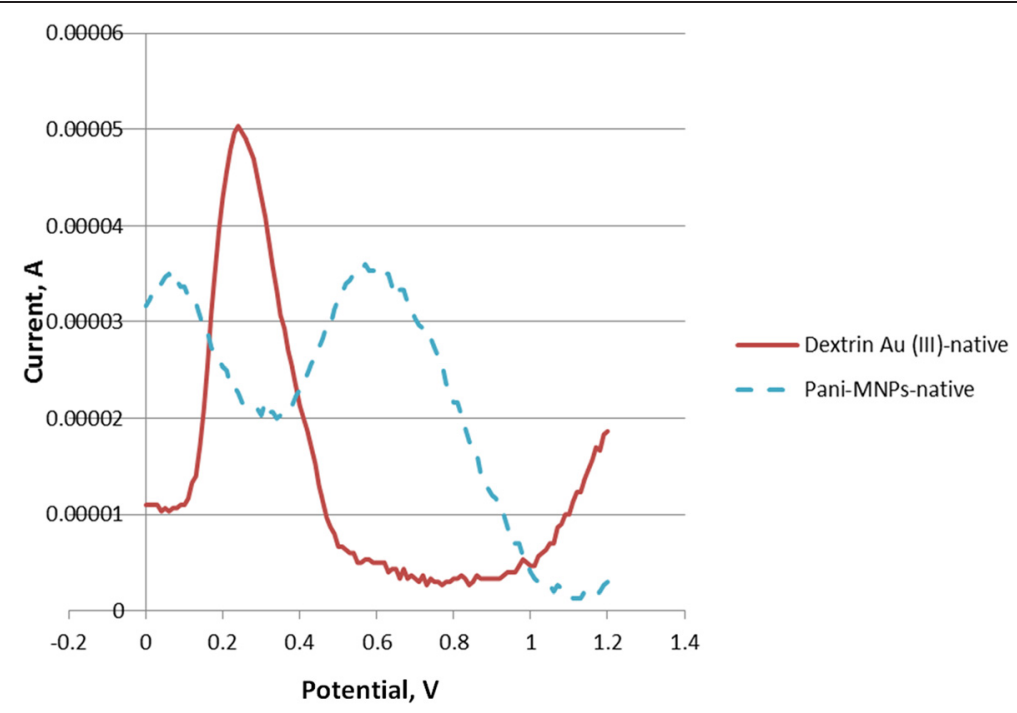

Fig. 4 Differential pulse voltammetric sensorgrams of the gold nanoparticle (AuNPs) and Polyaniline (PANI)-coated magnetic nanoparticles (MNPs). AuNPs show a current peak at $0.3 \mathrm{~V}$ and MNPs show a current peak at $0.58 \mathrm{~V}$

signal of this biosensor. The SNR for $10^{1}, 10^{2}, 10^{3}, 10^{4}$, $10^{5}$ and $10^{6} \mathrm{cfu} / \mathrm{ml}$ are $1.28,1.56,1.69,1.73,2.12$ and 2.36 , respectively. A statistical analysis using $t$ test was conducted and the results are presented in Table 1. As shown, cell concentration at $10^{1} \mathrm{cfu} / \mathrm{ml}$ has a $P$ value of 0.0546 (which is close to critical value of $P=0.05$ ). The $P$ value for other concentrations shows that the samples are significantly different from the blank. Therefore, the lowest cell concentration is weakly $10^{1} \mathrm{cfu} / \mathrm{ml}$ and strongly at $10^{2} \mathrm{cfu} / \mathrm{ml}$. These results verify that MNP-
Ab-cell-Ab-AuNP is an effective approach to highly sensitive detection. The specificity of the biosensor, which largely depends on the monoclonal antibody used in magnetic separation, was evaluated in another study by our lab [21]. An inclusivity of $94 \%$ and an exclusivity of $69 \%$ was obtained [21]. The inclusivity was calculated as the number of positive tests identified by the antibody divided by the actual total positive test number. The exclusivity was calculated as the number of negative tests identified divided by the actual total negative test

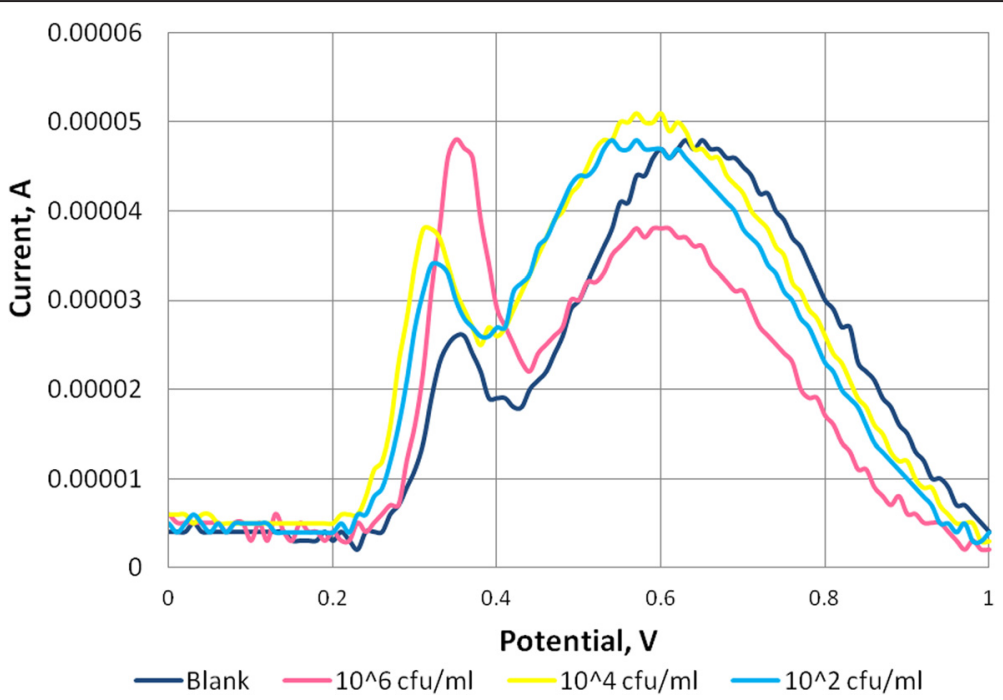

Fig. 5 Sensorgram of gold nanoparticle (AuNP)-labeled biosensor for E. coli O157:H7 detection. Peak current for AuNP at around 0.3 V increases with increasing cell concentrations 


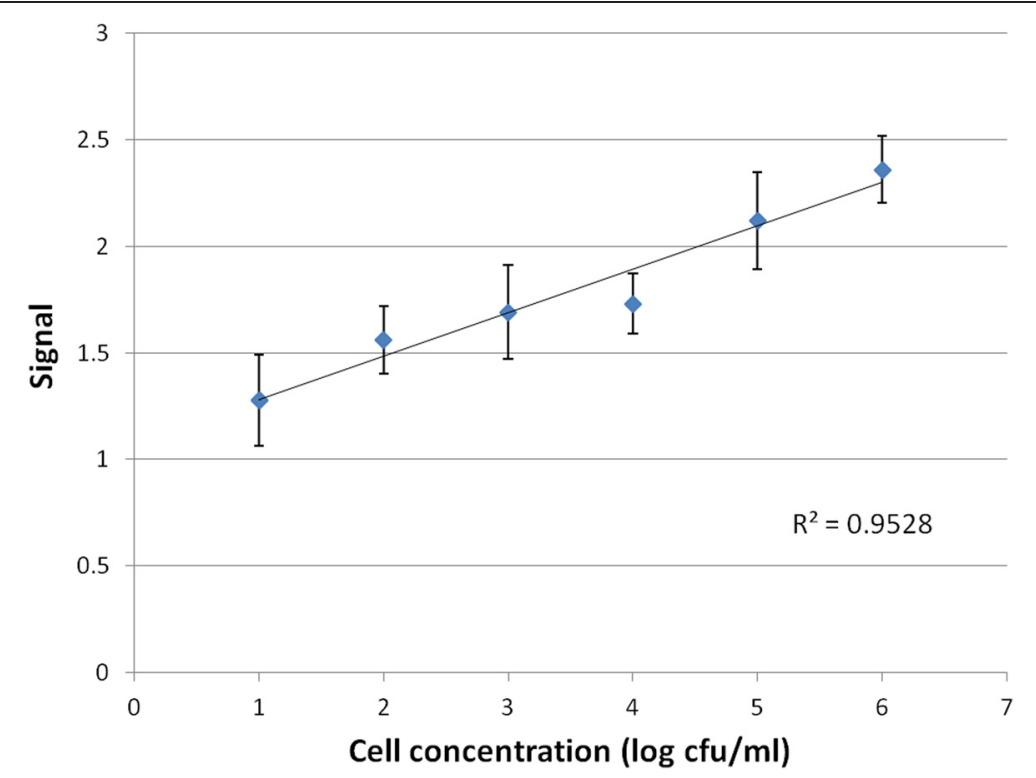

Fig. 6 Peak current vs. cell concentration of the gold nanoparticle (AuNP)-labeled biosensor for E. coli O157:H7 detection. The signal shows a linear relationship between $10^{1}$ to $10^{6} \mathrm{cfu} / \mathrm{ml}$

number. The specificity of the monoclonal and polyclonal Abs-based sandwich configuration was also verified in our previous study [8].

\section{Conclusions}

A AuNP-labeled biosensor has been developed for the sensitive and rapid detection of E. coli O157: H7. The lower limit of detection is at $10^{1} \mathrm{cfu} / \mathrm{ml}$ with a dynamic range of $10^{1}$ to $10^{6} \mathrm{cfu} / \mathrm{ml}$. Target extraction and detection are completed within $45 \mathrm{~min}$. Furthermore, sample preparation requires a simple magnet without special equipment. Due to its simplicity and rapid results, this biosensor has the potential for in-field use in quickly screening bacterial contamination in food products (e.g. ground beef, vegetables, and juices) and water systems. The biosensor is also a promising technology for pointof-care screening of diseases and environmental determination of harmful biological agents.

\section{Materials and methods Reagents and materials}

Two kinds of nanoparticles were synthesized: MNPs and AuNPs. Aniline, iron (III) oxide nanopowder, ammonium persulfate, methanol, and diethyl ether (Sigma-Aldrich, St. Louis, MO) were used for the synthesis of the MNPs. Gold (III) chloride trihydrate (Aldrich, MO) and

Table 1 Statistical analysis comparing samples and blank ( $t$ test) \begin{tabular}{lllllll}
\hline Concentration (cfu/ml) & $10^{1}$ & $10^{2}$ & $10^{3}$ & $10^{4}$ & $10^{5}$ & $10^{6}$ \\
\hline Pvalue
\end{tabular} \begin{tabular}{lllllll}
\hline$P$ value & 0.0546 & 0.0212 & 0.0044 & 0.0054 & 0.0079 & 0.0007
\end{tabular}

${ }^{*} P$ value was calculated by a one-tailed paired $t$ test. The critical value, $P=0.05$ dextrin (Fluka, MO) were used for the synthesis of AuNPs under alkaline conditions [22].

MNPs were functionalized with monoclonal anti-E. coli O157:H7 antibody obtained from Meridian Life Science, Inc (Saco, ME). AuNPs were conjugated with polyclonal anti- E. coli O157:H7 antibody from Meridian Life Science, Inc (Saco, ME). Protein A from Staphylococcus aureus (Sigma-Aldrich, St. Louis, MO) was used as the linkage agent for AuNP and antibody conjugation.

Triton-X100, phosphate buffered saline (PBS), casein, bovine serum albumin (BSA) and sodium phosphate (dibasic and monobasic) were obtained from SigmaAldrich (St. Louis, MO). PBS buffer $(0.01 \mathrm{M}$ and $0.1 \mathrm{M}$, $\mathrm{pH}$ 7.4), $0.01 \mathrm{M}$ PBS buffer with $0.05 \%$ (w/v) TritonX100, phosphate buffer (0.1 M sodium phosphate, $\mathrm{pH}$ 7.4), $0.01 \mathrm{M}$ PBS buffer with $0.01 \%$ casein, $0.01 \mathrm{M}$ PBS buffer with $0.1 \%(w / v)$ BSA were prepared with deionized water from Millipore Direct-Q system. PBS buffer and phosphate buffer were used in preparing nanoparticle-Ab conjugates and in washing. PBS buffer with casein or BSA was used to block nanoparticle surface against nonspecific binding. PBS buffer with Triton-X100 was used for washing off unbound or nonspecifically bound reactants after capture.

\section{Bacterial culture}

E. coli O157:H7 Sakai strain was obtained from the Nano-Biosensors Lab collection at Michigan State University. The colonies from frozen (stored at $-70{ }^{\circ} \mathrm{C}$ ) culture were grown on trypticase soy agar (BD Biosciences, $\mathrm{MD})$ plates. A single colony was isolated and inoculated in tryptic soy broth (BD Biosciences, MD) and grown 
overnight at $37{ }^{\circ} \mathrm{C}$. One milliliter of the liquid culture was transferred to another tube of tryptic soy broth and incubated overnight at $37{ }^{\circ} \mathrm{C}$. One milliliter of this liquid culture was transferred to a new tube of broth and incubated at $37^{\circ} \mathrm{C}$ for $6 \mathrm{~h}$ before each experiment. The serial dilutions of bacterial culture were prepared using $0.1 \%$ $(w / v)$ peptone water (Fluka-Biochemika, Switzerland) before each experiment. Viable cells were enumerated by microbial plating on Sorbitol MacConkey agar (SMAC, BD Biosciences, MD).

\section{Apparatus}

Electrochemical measurement was performed with a potentiostat/galvanostat (263A, Princeton Applied Research, MA) with a software operating system (PowerSuite, Princeton Applied Research, MA) on a computer connected to the potentiostat. The measurement was performed by introducing each sample onto a SPCE chip (Gwent Inc. England). The SPCE chip consisted of a working carbon electrode and a counter and reference silver/silver chloride electrode. One hundred microliters of each sample were introduced to the electrode area on the SPCE chip.

\section{Synthesis of nanoparticles}

PANI coated MNPs were synthesized according to our method [6]. Fifty milliliters of $1 \mathrm{M}$ hydrochloric acid, $10 \mathrm{ml}$ of water and $0.4 \mathrm{ml}$ of aniline monomer were mixed in a flask, and then $0.65 \mathrm{~g}$ of iron (III) oxide nanopowder were added to the solution to maintain a final $\gamma-\mathrm{Fe}_{2} \mathrm{O}_{3}$ : aniline weight ratio of 1 : 0.6. The mixture was put in a beaker filled with ice and sonicated for $1 \mathrm{~h}$. The solution was stirred while it was still on ice. During the stirring, ammonium persulfate ( $1 \mathrm{~g}$ of ammonium persulfate in $20 \mathrm{ml}$ deionized water) was added to the solution slowly for $30 \mathrm{~min}$. The solution was stirred for another $1.5 \mathrm{~h}$. After the reaction, the solution was filtered using $2.5 \mu \mathrm{m}$ filter paper and washed with $20 \%$ methanol. Hydrochloric acid (1 M) was used to wash until the filtrate became clear, followed by washing with $10 \mathrm{ml}$ of $20 \%$ methanol. The filtrate was filtered again using a $1.2 \mu \mathrm{m}$ filter paper, and $10 \mathrm{ml}$ of $20 \%$ methanol solution was added to the filter. The hydrochloric acid and methanol wash was repeated. The nanoparticles on the filter paper were left under a fume hood to dry for $24 \mathrm{~h}$ at room temperature and stored in a vacuum desiccator after drying.

AuNPs were synthesized under alkaline conditions following the approach published by Anderson et al [22]. Briefly, $20 \mathrm{ml}$ of dextrin stock solution $(25 \mathrm{~g} / \mathrm{l})$ and $20 \mathrm{ml}$ of sterile water were mixed in a $50 \mathrm{ml}$ sterile orange cap tube (disposable). Five milliliters of $\mathrm{HAuCl}_{4}$ stock solution $(8 \mathrm{~g} / \mathrm{ml})$ were then added, and the $\mathrm{pH}$ of the solution was adjusted to 9 with sterile $10 \%(\mathrm{w} / \mathrm{v})$
$\mathrm{Na}_{2} \mathrm{CO}_{3}$ solution. The final volume was brought to $50 \mathrm{ml}$ with $\mathrm{pH} 9$ water. The reaction was carried out by incubating the solution in a sterile flask in the dark at $50{ }^{\circ} \mathrm{C}$ with continuous shaking (100 rpm) for $6 \mathrm{~h}$. A red solution was obtained at the end of the reaction.

\section{Functionalization of nanoparticles}

MNPs were functionalized with a monoclonal anti-E. coli O157:H7 antibody [6]. MNPs (2.5 mg) were suspended in $150 \mu \mathrm{l}$ of $0.1 \mathrm{M}$ phosphate buffer, and sonicated for $15 \mathrm{~min}$. Monoclonal anti-E. coli O157:H7 antibody $(2.5 \mathrm{mg} / \mathrm{ml}, 100 \mu \mathrm{l})$ was added to the suspension, and hybridized on tube rotator for $5 \mathrm{~min}$. Twenty five microliters of PBS buffer $(0.1 \mathrm{M})$ were added. Then the conjugation was carried on for $55 \mathrm{~min}$ on the tube rotator. The MNPs were separated from the solution by magnetic separation, and blocked by adding $250 \mu \mathrm{l}$ of $0.1 \mathrm{M}$ tris buffer with $0.01 \%$ casein and incubated for $5 \mathrm{~min}$. This step was repeated three times, and the suspension was put on tube rotator for $1 \mathrm{~h}$ to hybridize. Finally, the MNPs were magnetically separated and resuspended in $2.5 \mathrm{ml}$ of $0.1 \mathrm{M}$ phosphate buffer. The MNP-Ab conjugate was stored at $4{ }^{\circ} \mathrm{C}$ before use.

AuNPs were conjugated with a polyclonal anti-E. coli O157:H7 antibody through protein A linkage. Two hundred microliters of 1:2 diluted suspension of AuNPs in water were put into a $2 \mathrm{ml}$ microcentrifuge tube and sonicated for $10 \mathrm{~min}$. Then the suspension was centrifuged for $6 \mathrm{~min}$ at 13,000 rpm. The supernatant was removed after centrifugation. To modify the surface of the AuNPs, protein A $(0.25 \mathrm{mg} / \mathrm{ml})$ in $200 \mu \mathrm{l}$ of $0.01 \mathrm{M} \mathrm{PBS}$ buffer was used to resuspend the AuNPs. The conjugation was conducted by rotating the mixture for $1 \mathrm{~h}$. The modified AuNPs were separated from the suspension by centrifugation for $6 \mathrm{~min}$ at 13,000 rpm. The nanoparticles were washed by adding $200 \mu \mathrm{l}$ of $0.01 \mathrm{M}$ PBS buffer and centrifuged. After removing the supernatant, $100 \mu \mathrm{l}$ of $1 \mathrm{mg} / \mathrm{ml}$ antibody and $100 \mu \mathrm{l}$ of $0.01 \mathrm{M}$ PBS buffer were added to the tube and mixed for $60 \mathrm{~min}$ by rotating. After separating the AuNP-antibody (AuNP-Ab) conjugates from the supernatant, $200 \mu$ l of PBS buffer with $0.1 \%(\mathrm{w} / \mathrm{v}) \mathrm{BSA}$ were added to the tube. The mixture was rotated for $30 \mathrm{~min}$. Finally, the AuNP-Ab conjugates were separated from the suspension by centrifugation, and the final suspension of the conjugates in $200 \mu \mathrm{l}$ PBS buffer with BSA was stored at $4{ }^{\circ} \mathrm{C}$.

\section{Detection of target pathogenic bacteria}

Detection of the target pathogen is presented in Fig. 1. Blank control for the tests was peptone water in the same volume as the sample. Firstly, $400 \mu \mathrm{l}$ of $0.01 \mathrm{M}$ PBS buffer, $50 \mu \mathrm{l}$ of cell dilution (or peptone water for the blank) and $50 \mu \mathrm{l}$ of MNP-Ab conjugates were combined in a $2 \mathrm{ml}$ sterile tube. After $15 \mathrm{~min}$ hybridization, 
PBS buffer ( $55 \mu \mathrm{l}, 0.01 \mathrm{M}$ ) with $0.1 \%$ BSA was added to the mixture as a blocking agent. Then, the MNP-E. coli complexes were magnetically separated from the solution and resuspended in $450 \mu \mathrm{l}$ of $0.01 \mathrm{M}$ PBS buffer. Secondly, $50 \mu \mathrm{l}$ of the AuNP-Ab conjugates were introduced to the system, followed by 15 min hybridization. After washing the complexes once with 0.01 M PBS buffer, the complexes were resuspended in $500 \mu \mathrm{l}$ of PBS buffer with $0.05 \%$ Triton-X100, and let stand for $3 \mathrm{~min}$. Finally, the complexes were magnetically separated from the buffer and resuspended in $500 \mu \mathrm{l}$ of $0.01 \mathrm{M}$ PBS buffer. One hundred microliters of the suspension were plated on SMAC for cell counting. The rest of the complexes were magnetically separated from the supernatant $(400 \mu \mathrm{l})$.

\section{Electrochemical measurement}

The target bacteria were detected by measuring the electrochemical signal of AuNPs. Each sample from the last section (complexes magnetically separated from supernatant) in $100 \mu \mathrm{l} 1 \mathrm{M}$ hydrochloric acid was introduced to the SPCE chip. An oxidation potential of $1.4 \mathrm{~V}$ vs. $\mathrm{Ag} / \mathrm{AgCl}$ was applied to the working electrode. After oxidation, a differential pulse voltammetric (DPV) measurement was performed. The scan was from $1.5 \mathrm{~V}$ to $-1.5 \mathrm{~V}$. The potential and currents were recorded. All measurements were performed at room temperature. Each sample was measured three times. At least three samples of each concentration of bacteria were tested.

\section{Abbreviations}

AuNPs: Gold nanoparticles; MNPs: Magnetic nanoparticles; DPV: Differential pulse voltammetry; SPCE: Screen printed carbon electrode; TEM: Transmission electron microscopy; PANI: Polyaniline; Ab: Antibody; SEM: Scanning electron microscopy; SNR: Signal to noise ratio; PBS: Phosphate buffered saline; BSA: Bovine serum albumin; SMAC: Sorbitol MacConkey agar.

\section{Competing interests}

The authors declare that they have no competing interests.

\section{Authors' contributions}

YW contributed to experimental design, carried out the experiments and drafted the manuscript. ECA conceived and designed the experiments, participated in discussions, and drafted the manuscript. Both authors read and approved the final manuscript.

\section{Acknowledgements \\ This project was funded by the Michigan State University Strategic Partnership Grant through A-CAPPP (Anti-Counterfeiting and Product Protection Program) and by the MSU Targeted Support Grants for Technology Development Project. The authors would like to thank Patrick Fewins for his assistance in the experiments.}

\section{Author details}

${ }^{1}$ Department of Biosystems and Agricultural Engineering, Michigan State University, East Lansing, Ml 48824, USA. ${ }^{2}$ resent address: Division of Food Processing Science and Technology, U. S. Food and Drug Administration, Bedford Park, IL 60501, USA.

Received: 17 August 2015 Accepted: 15 September 2015

Published online: 02 October 2015

\section{References}

1. United States Centers for Disease Control and Prevention (CDC). Multistate Outbreak of E. coli 0157:H7 Infections Linked to Eating Raw Refrigerated, Prepackaged Cookie Dough. 2009. http://www.cdc.gov/ecoli/2009/0630.html. Accessed 9 Jun 2015.

2. CDC. Investigation Announcement: Multistate Outbreak of E. coli O157:H7 Infections Linked to Romaine Lettuce. 2011. http://www.cdc.gov/ecoli/2011/ ecoliO157/romainelettuce/120711/. Accessed 9 Jun 2015.

3. CDC. Multistate Outbreak of Shiga toxin-producing Escherichia coli 0157:H7 Infections Linked to Ground Beef. 2014. http://www.cdc.gov/ecoli/2014/ 0157H7-05-14/index.html. Accessed 9 Jun 2015.

4. Luo Y, Nartker S, Miller H, Hochhalter D, Wiederoder M, Wiederoder S, et al. Surface functionalization of electrospun nanofibers for detecting $E$. coli 0157:H7 and BVDV cells in a direct-charge transfer biosensor. Biosens Bioelectron. 2010;26(4):1612-7.

5. Radke SM, Alocilja EC. A high density microelectrode array biosensor for detection of E. coli 0157:H7. Biosens Bioelectron. 2005;20(8):1662-7.

6. Setterington EB, Cloutier BC, Ochoa JM, Cloutier AK, Jain P, Alocilja EC. Rapid, sensitive, and specific immunomagnetic separation of foodborne pathogens. Int J Food Saf Nutr Public Health. 2011;4(1):83-100.

7. Wang Y, Wang R, Li Y, Srinivasan B, Tung S, Wang H, et al. Detection of Escherichia coli 0157:H7 using interdigitated array microelectrode-based immunosensor. Biol Eng. 2010;2(2):49-62.

8. Wang Y, Fewins P, Alocilja EC. Electrochemical Immunosensor Using Nanoparticle-based Signal Enhancement for Escherichia coli 0157:H7 Detection. Sensors Journal, IEEE. 2015; 15(8):4692-9.

9. Linman MJ, Sugerman K, Cheng Q. Detection of low levels of Escherichia coli in fresh spinach by surface plasmon resonance spectroscopy with a TMB-based enzymatic signal enhancement method. Sensors Actuators B Chem. 2010;145(2):613-9.

10. Park S, Kim H, Paek S, Hong JW, Kim Y. Enzyme-linked immuno-strip biosensor to detect Escherichia coli 0157:H7. Ultramicroscopy. 2008;108(10):1348-51.

11. Sun H, Choy TS, Zhu DR, Yam WC, Fung YS. Nano-silver-modified PQC/DNA biosensor for detecting E. coli in environmental water. Biosens Bioelectron. 2009;24(5):1405-10.

12. Wang L, Liu Q, Hu Z, Zhang Y, Wu C, Yang M, et al. A novel electrochemical biosensor based on dynamic polymerase-extending hybridization for E. coli 0157:H7 DNA detection. Talanta. 2009;78(3):647-52.

13. Council for Agricultural Science and Technology (CAST). Foodborne Pathogens: Risks and Consequences. 1994. Report No. 122.

14. Li K, Lai Y, Zhang W, Jin L. Fe2O3@Au core/shell nanoparticle-based electrochemical DNA biosensor for Escherichia coli detection. Talanta. 2011;84(3):607-13.

15. Zhang D, Huarng MC, Alocilja EC. A multiplex nanoparticle-based biobarcoded DNA sensor for the simultaneous detection of multiple pathogens. Biosens Bioelectron. 2010;26(4):1736-42.

16. Hao R, Song H, Zuo G, Yang R, Wei H, Wang D, et al. DNA probe functionalized QCM biosensor based on gold nanoparticle amplification for Bacillus anthracis detection. Biosens Bioelectron. 2011;26(8):3398-404.

17. Jiang $X$, Wang $R$, Wang $Y$, Su X, Ying $Y$, Wang J, et al. Evaluation of different micro/nanobeads used as amplifiers in QCM immunosensor for more sensitive detection of E. coli O157:H7. Biosens Bioelectron. 2011;29(1):23-8.

18. Pal S, Alocilja EC. Electrically active polyaniline coated magnetic (EAPM) nanoparticle as novel transducer in biosensor for detection of Bacillus anthracis spores in food samples. Biosens Bioelectron. 2009;24(5):1437-44.

19. Hyeon T, Lee S, Park J, Chung Y, Bin NH. Synthesis of highly crystalline and monodisperse maghemite nanocrystallites without a size-selection process. J Am Chem Soc. 2001;123(51):12798-801.

20. Shaikh SF, Lim JY, Mane RS, Han S, Ambade SB, Joo O. Wet-chemical polyaniline nanorice mass-production for electrochemical supercapacitors. Synth Met. 2012;162(13-14):1303-7.

21. Cloutier BC. Development of mitigation strategies toward preventative postures in food defense. Ph.D. United States, Michigan: Michigan State University; 2012.

22. Anderson MJ, Torres-Chavolla E, Castro BA, Alocilja EC. One step alkaline synthesis of biocompatible gold nanoparticles using dextrin as capping agent. J Nanopart Res. 2011;13(7):2843-51. 